\title{
Schwannoma of the left superior eyelid in a 10-year-old child
}

\section{Schwannoma em pálpebra superior esquerda em criança de 10 anos}

Marília de Sá Coutinhoํ, Isadora Meyer ${ }^{2}$, Patrícia Jungmann³, João Pessoa de Souza Filho4

\begin{abstract}
Schwannoma is a rare benign neurogenic tumor. It arises from Schwann cells located at the myelin sheath of peripheral nerves. Its incidence is frequently associated with the orbit. Ocular tissues in general and eyelids in particular are rarely affected. Very few reports can be found in the literature describing eyelid schwannomas. Amongst these, we have found only two describing it affecting children. To our knowledge, this is the first case report about eyelid schwanomma in Brazil - and it involves a child.

Keywords:Neurilemmoma/pathology; Neurilemmoma/surgery; Eyelid neoplasms/pathology; Eyelid neoplasms/surgery; Child; Case reports
\end{abstract}

\section{RESUMO}

Schwannoma é um tumor neurogênico benigno raro, originário das células de Schwann da bainha de mielina dos nervos periféricos. Sua localização nos tecidos oculares não é comum, sendo a órbita o local afetado com maior frequência e o acometimento das pálpebras é muito raro. Há poucos relatos descritos na literatura sobre Schwannoma palpebral, apenas dois em crianças. Este é, em nosso conhecimento, o primeiro caso relatado no Brasil.

Descritores: Neurilemoma/patologia; Neurilemoma//cirurgia; Neoplasias palpebrais/patologia; Neoplasias palpebrais/cirurgia; Criança; Relatos de casos

\footnotetext{
${ }^{1}$ Resident in Ophthalmology, Recife Eye Institute, Recife/PE, Brazil;

${ }^{2}$ Trainee at the Cornea and Refractive Surgery Unit, Santa Casa de Misericórdia, Belo Horizonte/MG, Brazil;

${ }^{3}$ Adjunct Professor of Pathology, University of Pernambuco (UPE), Recife/PE, Brazil;

${ }^{4}$ Adjunct Professor of Ophthalmology, Federal University of Paraíba (UFPB), João Pessoa/PB, Brazil; Federal University of Campina Grande (UFCG), Campina Grande/PB, Brazil.
}

Institution: Recife Eye Institute, Recife/PE, Brazil;

The authors declare no conflict of interest. 


\section{INTRODUCTION}

$\mathbf{S}$ chwannoma or neurilemmoma is a rare benign neurogenic tumour originating from the Schwann cells of the myelin sheath of peripheral nerves ${ }^{(1-11)}$. It is a slow-growing encapsulated tumour that seldom affects ocular tissues. The orbit is the most frequently-affected site (1-2\% of all orbital tumours), while the eyelids are very rarely involved ${ }^{(1-11)}$. It usually develops in adults as an isolated tumour or in association with neurofibromatosis ${ }^{(2,5)}$. When isolated it is rarely associated with neurofibromatosis ${ }^{(5)}$, since the presence of multiple schwannomas is usually indicative of the condition ${ }^{(2)}$.

There are few reports of eyelid schwannoma in the literature ${ }^{(1-11)}$, and the case reported here is, to our knowledge, the first in Brazil.

\section{CASE REPORT}

Ten-year-old female patient complaining of a lump in the lateral corner of the upper left eyelid; the patient was diagnosed with chalazion and underwent surgical excision. During surgery it was noted that the lesion's appearance was not compatible with the medical diagnosis of chalazion, but suggestive of a hard, well-demarcated tumour of the subcutaneous tissue with benign features. The lesion was excised and submitted to histopathology. Macroscopic examination showed an irregular fragment of whitish, compact, elastic tissue measuring $1.1 \times 0.7 \times 0.2 \mathrm{~cm}$. Microscopic examination showed histological sections consisting of spindle-shaped cells with oval nuclei and elongated oval cytoplasm forming bundles, most of them loose, corresponding to the Antoni A pattern for schwannoma, as well as small areas corresponding to the Antoni B pattern (Figure 1A). The lesion was diagnosed as a schwannoma (neurilemmoma) with a histopathological predominance of the Antoni A pattern.

Immunohistochemical examination of the lesion showed that the tissue was immunopositive for the S-100 protein and immunonegative for the other tested proteins (melan-A, smooth muscle actin, GEAP [glial fibrillary acidic protein], and the Ki67 antigen), with evidence of low cell proliferation (Figure 1B). These tests confirmed the diagnosis of schwannoma.

The patient recovered well postoperatively with complete wound healing. After six months there were no signs of relapse. The patient is still undergoing follow-up.

\section{DisCUSSION}

Schwannomas or neurilemmomas are slow-growing benign tumours of the cranial and peripheral nerves. Their origin is ectodermal and they are derived from the Schwann cells of the myelin sheath ${ }^{(1-10)}$. Schwannomas are firm encapsulated tumours with solid and cystic areas and a brown-yellow colour. They are asymptomatic ${ }^{(5)}$.

Schwannomas can be associated with neurofibromatosis, but when isolated they are not related to this condition ${ }^{(2,5)}$.

Schwannomas occur in two histological patterns. The Antoni A pattern, found in the patient presented here, presents with spindle-shaped cells arranged in compact stacks, usually in palisades. The Antoni B pattern is characterised by cells dispersed in a myxoid matrix $x^{(3,5,6)}$.

Eyelid schwannomas are extremely rare and usually occur in adults ${ }^{(2-7,9,10)}$. Only two other cases have been reported in children ${ }^{(1,8)}$. The patient presented here was 10 years old at the time of diagnosis. Among the cases reported in the literature, the incidence in males and females seems to be similar (there are reports of schwannoma in 6 males 8 females, including the case presented here) (Table 1).

Ocular schwannomas are more common in the orbit, representing $1-2 \%$ of orbital tumours ${ }^{(1,5,6)}$, while eyelid schwannomas are extremely rare ${ }^{(6,9)}$. There are also reports of schwannomas in the conjunctiva, sclera, and uveal tract ${ }^{(1,2,5,9)}$. Orbital schwannomas usually originate from the oculomotor, ciliary, and supraorbital nerves. Eyelid schwannomas are believed to originate from branches of the supraorbital, supratrochlear, and infraorbital nerves ${ }^{(1)}$.

Schwannomas manifest clinically as solid, painless, slowgrowing masses which are often confused with chalazion ${ }^{(2,49)}$ or inclusion $\operatorname{cysts}^{(2,5)}$. The differential diagnosis should include chalazion, sweat gland tumour, sebaceous gland carcinoma, hair follicle tumour, and other neurogenic and soft tissue tumours ${ }^{(9)}$.

Schwannomas can rarely become malignant ${ }^{(2)}$. Computed tomography is important to delineate the tumour for surgery, as the lesion has to be excised completely to prevent relapse or malignant transformation ${ }^{(4,7-11)}$.

The diagnosis of eyelid schwannoma can be suggested by clinical examination and imaging studies in conjunction with its macroscopic appearance during surgery; however, because the condition is so rare, it is seldom considered in the differential diagnosis of eyelid masses and the diagnosis is often made by

Table 1

\begin{tabular}{|c|c|c|c|c|}
\hline \multicolumn{5}{|c|}{ Reported cases of eyelid Schwannoma. } \\
\hline Author & Year & Country & Sex & Age \\
\hline Mishra, Sharan (11) & 1960 & India & Male & 18 years \\
\hline Baijal et al. ${ }^{(10)}$ & 1980 & Índia & Male & 19 years \\
\hline Shields, Guibor ${ }^{(9)}$ & 1984 & USA & Female & 63 years \\
\hline Butt, Ironside ${ }^{(7)}$ & 1994 & England & Female & 55 years \\
\hline Shields et al. ${ }^{(8)}$ & 1994 & USA & Male & 8 years \\
\hline Siddiqui et al. ${ }^{(6)}$ & 2005 & England & Male & 53 years \\
\hline Chung et $\mathrm{al} .{ }^{(4)}$ & 2007 & Korea & Female & 66 years \\
\hline López-Tizón et al.(5) & 2007 & Spain & Female/Female & 41 years $/ 70$ years \\
\hline Kumar et al.(3) & 2008 & India & Male & 19 years \\
\hline Touzri et al. ${ }^{(2)}$ & 2009 & Tunisia & Male/Female & 47 years/20 years \\
\hline Onaran et al. ${ }^{(1)}$ & 2009 & TurKey & Female & 13 years \\
\hline
\end{tabular}


histopathological examination ${ }^{(1-11)}$, as was the case with our patient. However, it is a hypothesis to be considered, especially in cases of recurrent chalazion. It is also important to search for similar lesions in other areas of the body in order to investigate neurofibromatosis, since schwannomas can be associated with this condition ${ }^{(2,5)}$. In our case no signs of the disease were found.

Schwannomas in the ocular region are rare, although they represent approximately $1-2 \%$ of orbital tumours ${ }^{(1,5,6)}$. Eyelid schwannomas are extremely $\operatorname{rare}^{(6,9)}$. Although uncommon, schwannomas should be included in the differential diagnosis of any eyelid tumour.

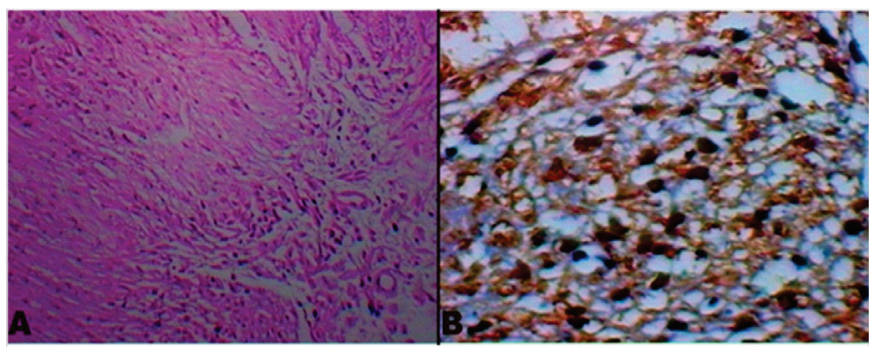

Figure 1: A) Histological sections showing a proliferation of spindleshaped cells with oval nuclei and elongated oval cytoplasm forming bundles, most of them loose, corresponding to the Antoni A pattern for schwannoma, as well as small areas corresponding to the Antoni B pattern. B) The tissue was immunopositive for the S-100 protein.

\section{RefERENCES}

1. Onaran Z, Ornek K, Yilmazbas P, Bozdogan O. Schwannoma of the lower eyelid in a 13-year-old girl.Ophthal Plast Reconstr Surg.2009;25(1):50-2.
2. Touzri RA, Errais K,Zermani R, Benjilani S, Ouertani A. Schwannoma of the eyelid: apropos of two cases. Indian J Ophthalmol. 2009;57(4):318-20.

3. Kumar S, Kumar S, Kulshrestha R. Cystic schwannoma of the eyelid in an Indian male: a rare presentation. Orbit. 2008; 27(6):407-9.

4. Chung YR, Moon S, Jang JW. Eyelid schwannoma in a Korean woman. Jpn J Ophthalmol.2007;51(3):231-2.

5. López-Tizón E, Mencía-Gutiérrez E, Gutiérrez-Díaz E, Ricoy JR. Schwannoma of the eyelid: report of two cases. Dermatol Online J.2007;13(2):12.

6. Siddiqui MA, Leslie T, Scott C, Mackenzie J. Eyelid schwannoma in a male adult. Clin Experiment Ophthalmol.2005;33(4):412-3.

7. Butt Z, Ironside JW. Superficial epithelioid schwannoma presenting as a subcutaneous upper eyelid mass. Br J Ophthalmol. 1994;78(7):586-8.

8. Shields JA, Kiratli H, Shields CL,Eagle RC Jr, Luo S. Schwannoma of the eyelid in a child. J Pediatr Ophthalmol Strabismus.1994;31(5):3323.

9. Shields JA, Guibor P. Neurilemoma of the eyelid resembling a recurrent chalazion. Arch Ophthalmol.1984;102(11):1650.

10. Baijal GC, Garg SK, Kanhere S, Monga S. Schwannoma of the eye-lid. Indian J Ophthalmol.1980;28(3):155-6.

11. Mishra S, Sharan J. Palpebral neurilemmoma. Br J Ophthalmol. 1960;44:252.

\section{Corresponding author:}

Marília Coutinho

Rua Vicente Meira, 137, CEP: 52.020-130, Recife/PE, Brazil. Telephone: +55813271 0633 / +55819921 3244. Fax: +5581 34235353.

E-mail: msacoutinho@gmail.com 